\title{
Influence of Gender and Age of Teachers on Teaching: Students Perspective
}

\author{
Shilpa Rajesh Shah* and Usha Subodh Udgaonkar \\ Department of Microbiology, Bharati Vidyapeeth University Medical College and Hospital, \\ Sangli-416410, Maharashtra, India \\ *Corresponding author
}

\section{A B S T R A C T}

Teaching is an ability of teacher to efficiently impart knowledge. An effective teacher will be one, who is competent, has knowledge and skill and is a performer i.e. he can use knowledge and skill in a classroom to accomplish a teachers' goal. It is said that

Keywords

Teaching, Gender, Age, Experience, Medical teacher

Article Info

Accepted:

16 December 2017

Available Online:

10 January 2018 experience and age has a positive effect on teaching. But over a period of time, there is a change in observations. Students' views are changing. In few of the recent studies students have chosen teachers with good knowledge, communication skills and student friendly nature. So we planned to take students feedback regarding their choice of gender and age of teacher in our classroom teaching. A questionnaire was provided to 75 second year MBBS students, which consisted questions regarding their choice for the gender, age and experience of teachers (either male or female, young or old, experienced or inexperienced) and their reasons behind them. Also a separate space was provided for any specific remarks of the students. In this study most of the students did not feel gender or age as a barrier in teaching until the teacher is active and interested in teaching and they felt, experience has a positive influence on teaching. But it is observed that the females preferred females as they thought it was easy to interact with them. Many students felt females are compassionate, hardworking sincere enough and have got high pitched voice which is audible.

\section{Introduction}

A Medical Institution could be considered as a system and medical teachers are the architects and builders of student's behavior. Teachers are also curricular developers and trans-actors and thus have a pivotal role in shaping the future medicos (Bhuiyan et al., 2001). Medical education empowers the students with knowledge, proper attitude and skill. A teacher must possess qualities like knowledge, skill, decision making and enthusiasm to teach. Students have their own way of thinking for discrimination between different characteristics of the teachers, and hence teaching becomes a challenging job (Kothari et al., 1996). Technological advancement and knowledge explosion are advancing at a jet speed (Bhuiyan et al., 2001). To keep up with the latest, the medical educators must update their knowledge at regular intervals. Information about reactions to a person's performance is feedback. Students feedback is the most commonly used feedback system for evaluation of teachers, their salary and 
promotion decisions. It is a common thinking that age, gender and experience has an effect on teaching. The first impression was more the age and experience, better is the teacher. It was as simple as that. But in many of the recent studies different opinions of the students were noted. Hence we decided taking a feedback from the learners in our institute to know their perspectives regarding teacher's age, sex and teaching experience, that affect learning in a class room.

\section{Materials and Methods}

A questionnaire (feedback form) was provided to 75 second year MBBS students, after ethical consideration. The attributes for feedback were preference of gender and age of teachers and the reason for the preference. A separate column was provided for their additional comments on the forms regarding additional suggestions or comments.

It was an anonymous feedback so that students could give their opinions without any restrictions. The questionnaire, instructions and the response obtained is as follows.

Student feedback form-

Student information - Year - II MBBS; Gender - M/F (Feedback form details showed in Table 1 and 2).

\section{Results and Discussion}

The process of becoming a doctor and a member of the medical profession is a social one. Professional socialization requires a medical curriculum, which would include training in communication skill, medical ethics, health economics, knowledge of the subject and now awareness of consumer's right (Bhuiyan et al., 2000). To achieve this goal it is the need of the hour to recruit best teachers in the Medical Colleges to impart training to the medical graduates as well as postgraduates. The process of this recruitment has been many a times dependent on the outcome of the student's feedback. Students' evaluations provide rich information about teaching. We considered two important variables, the gender and age of the teacher affecting the teaching - learning process in a classroom. The results are discussed from student's perspectives.

\section{Gender of the teacher}

Out of 75, 44\% (33) of the students preferred ladies as teacher, whereas preference for male teacher was $27 \%$ (20) and 29\% (22) of students were neutral. This observed difference between preference for ladies and gents was statistically not significant i.e. $\mathrm{P}>$ 0.05. But still many students preferred ladies as teacher and the reasons attributed were, their sincerity, hard work, efforts taken in preparing lectures, politeness and high pitch audible voice quality.

Literature points out that students are little biased to female teachers, which may be related to variety of factors like empathic listening, better understanding and view of concern shown by them(Feldman KA,. 1993). In one of the recent study by Bodhe et al., students do not find sex of the teacher worth discrimination (Bodhe et al., 2015). A well dressed, clean and neat teacher produces good first impression, very well draws the attention of the students and facilitates the further process of learning (Bar et al., 2006, Willis et al., 2006). In our study, there is no significant difference for preference of male or female teacher but, from the remarks of students it was obvious that girls felt they could interact better with lady teachers. Very few boys in our study were bold enough to remark that opposite sex attracted. Students who preferred male teacher remarked that males have better control of class, and because of their commanding nature and strictness they involved back benchers also. Students expect 
male professors to be effective in their work but expect female professors to spend time, building supportive relationships with students. According to Kierstead and his colleagues (Kierstead et al., 1988) male professors earned better student evaluations if they demonstrated competence but female professors had to demonstrate both competence and warmth to obtain the same high ratings.

\section{Age of the teacher}

Many positive and negative views have been put forward regarding age and teaching. It is a general thought that as age advanced and designation is promoted, teachers loose the enthusiasm to teach. Another thought was that age and experience go hand in hand. Age is an asset.

Because as the age advanced the teacher becomes experienced and he knows where to tap the potential of the students and how to make him understand his worth. Some feel that the teacher's enthusiasm deteriorated as the age advanced which may be due to the boredom of teaching same content over several years and added responsibilities on academic, administrative and research aspects (David, 1972). It was also noted that students respected senior Staff while neglecting the juniors as they felt that marks and their grades were governed by senior staff members (Marsh et al., 2000). However newer recruits or young teachers tried to imitate senior teachers, they had an urge for improvement. They could very well make use of audiovisual aids, mikes and other techniques for improving their teaching capabilities. These were few positive points in favor of younger teachers. The experience increased as the age advanced. Age is traditionally an asset to an individual, a most accessible variable, which is added to a person's resume. The previous successful tenure, and previous trainings were considered most important variables for promotion of teachers. In our study age of the teacher was not taken as important attribute by the students. $44 \%$ (33) of the students preferred young and $43 \%$ (32) preferred older teachers while $13 \%$ of them did not have specific age preference. This data for preference of age by students was not statistically significant. ( $\mathrm{P}$ value $>0.05)$ Bodhe et al., also had similar findings (Bodhe et al., 2015).

In view of all these, it is quite obvious that more recently the students did not consider the age of the teachers and the looks of the teacher important. They have their own views. In special remarks our students also suggested that knowledge of the teacher, clarity of thought or idea, the concept, its explanation, confidence of teacher, the organization of lecture material, command over the language and the subject, the classroom control and use of proper audiovisual aids with recent knowledge are more important attributes. Use of innovative and creative teaching techniques and student learning activities prevent boredom. However these are supplementary not a substitute to a teacher.

Student's feedback help Professors to consider changes such as teaching style, course content and classroom policies in an effort to help students learn and retain information. The opportunity for reflection is perhaps the most powerful benefit of evaluation. At many colleges evaluations also are used to determine raises, promotions, tenure and even teaching awards. In support of widespread use, data indicate that teaching evaluations can be good indicators of teaching effectiveness (Marsh et al., 1997). Unfortunately student evaluations may be biased based on characteristics of instructors themselves, such as their gender, age and attractiveness. (Shauna et al., 2015) 


\section{Kindly Tick / fill appropriate options}

\begin{tabular}{|c|c|c|}
\hline & Teacher & Why? \\
\hline $\begin{array}{l}\text { Whether you would like to } \\
\text { be taught by }\end{array}$ & Male/ Female & \\
\hline $\begin{array}{l}\text { Whether you would like to } \\
\text { be taught by }\end{array}$ & Young / Old & \\
\hline
\end{tabular}

Any other specific remark?

\section{Table.1 Student's feedback (Gender)}

\section{Preference for teachers}

\begin{tabular}{|l|l|l|l|}
\hline Male & Female & No Preference & Total \\
\hline $20(27 \%)$ & $33(44 \%)$ & $22(29 \%)$ & $75(100 \%)$ \\
\hline
\end{tabular}

$\mathrm{P}=0.056, \mathrm{Z}$ test $=1.908$ Standard error of Difference between 2 proportions.

$\mathrm{P}>0.05$ statistically not significant

There was no observed difference for preference to any gender.

Table.2 Student's feedback (Age)

\section{Preference for teachers}

\begin{tabular}{|l|l|l|l|}
\hline Young & Old & No Preference & Total \\
\hline $33(44 \%)$ & $32(43 \%)$ & $10(13 \%)$ & $75(100 \%)$
\end{tabular}

$\mathrm{Z}=0.12, \mathrm{P}=0.9$

$\mathrm{P}$ Value $>0.05$ statistically not significant, No Observed difference for preference to any age.

Contradictory to the old finding that as the age advances there is burnout (Jackson et al., 1993; Song, 2008). In a recent study (Biyani et al., 2013) no difference was found in the burnout between teachers with less teaching experience and teacher with more teaching experience. Similarly our students did not discriminate teachers in terms of their age, as long as they are teaching effectively, enthusiastically, with effective communication and problem solving. Good teaching is essentially a good communication. It involves transfer of knowledge rather than information to students igniting their capacity to think and making them acquire good skills.

Using data for a broad sample of instructors collected from the popular, but controversial Rate My professor (RMP) website it is found that age apparently does affect perceived teaching effectiveness. Instructor age is negatively related to student RMP ratings of faculty across all groups of academic disciplines and types of institutions for both men and women. However this age effects do not seem to increase even if they reach the former retirement ages. Moreover, the quantitative impact of age on RMP ratings is small and is often set aside by other factors, especially the instructors' physical appearance. For example, when we restrict the sample to those professor deemed "hot" by student raters, the effect of age disappears completely (Stonebraker et al., 2015).

In our study students did not give much importance to the gender as well as age of the teacher. There is no clear preference while many had opted more for female teachers, which they have attributed to their sincerity, a 
better compassionate approach towards the students, understanding their difficulties and helping them out. Students have also given importance to the knowledge of the teachers, their communication skills, command on the language, the subject i.e. their conceptual understanding and imparting the same knowledge to students. But this is a small group and the findings cannot be generalised. So a multicentric study with a bigger student group must be done. But it is very clear from student's feedback that teachers can avoid monotonous routine to avoid burnout, can change the topics regularly, and keep students interest alive by using innovative newer methods, like use of power point, internet and clinical photographs. One can interact with students frequently, can arrange for integrated teaching and can tactfully involve students in classroom teaching. Teaching is an art. Only few are born teachers, one can surely try and develop teaching skills. A comprehensive student feedback will definitely help in judging the teaching ability of teachers and will gain teachers appraisal.

A dedicated, intelligent, hardworking and knowledgeable teacher gains respect of students irrespective of age, sex and designation.

\section{Acknowledgement}

We are thankful to Mrs. Alka Gore, statistician, Department of PSM, BVUMCH Sangli for her help in statistical analysis.

\section{References}

Bar M. Neta M. and Linz H. 2006. Very first impression, Emotion. 6(2): 269-278.

Bhuiyan P S, Rege N.N. 2001. Evolution of Medical Education Technology Unit in India. J. Postgrad Med.; 47: 42.
Bhuiyan PS, Do we need to change. The Indian practitioner 2000, 53(9): 584585.

Biyani, A.A., Bagheri H., Bayani A. Influence of Gender, Age and years of teaching experience on Burnout. Annals of Biological Research, 2013 4(4): 239243.

Bodhe C.D., and Jankar D. S. Teaching effectiveness: how do students evaluate their teacher? International J. of healthcare and Biomedical Research, Volume 63, Issue: 02, January 2015. Pp. 155-159.

David Sinclair, Basic Medical Education, Oxford University Press, 1972, 3: 48-52 senior staff is more involved in academic work and research responsibility than teaching itself.

Feldman K.A. 1993. College student's views of male and female college teachers part II - Evidence from student's evaluations of their classroom teachers Research in higher education, 34: 151211.

Jackson RA, Richard A., Analysis of Burnout among school of pharmacy faculty. Am J. Pharmaeut, Edue, 1993 57(1): 9-17.

Kierstead, D.D., Agostion, P. and Dill H, 1988. Sex role stereotyping of college Professors; Bias in students rating of instructors. Journal of Educational Psychology, 80(3): 342-344.

Kothari M., Mehta L., Jogalekaer S., Bhiiyani $\mathrm{P}$. The art of teaching medical students, MET cell, SGMC and KEMH, Mumbai 1996; Pp. 42-50.

Marsh H.W. and Roche L.A. 1997. Making student evaluations of teaching effectiveness effective. The critical issues of validity bias and utility. American Psychologist 52(11): 11871197.

Marsh H.W. and Roche L.A. 2000. Effects of grading leniently and low workload on students' evaluation of teaching: 
Popular myth, bias validity of Song Z., Front Education, China, 2008, 3(2): Educational Psychology, 92: 202-22. 295-302

Shauna W. Joye and Janie $\mathrm{H}$ Wilson. Stonebraker Robert J. and Gary S. Stone. Res Professor Age and Gender Affect Student Perceptions and Grades. Journal of the Scholarship of Teaching and Learning. 15(4), August 2015 PP. 126138. High Edu., 56 (8): 793-812.

Willis J. and Todorov A. 2006. 'First impressions' Psychological science, 17(7): 592-598.

\section{How to cite this article:}

Shilpa Rajesh Shah and Usha Subodh Udgaonkar. 2018. Influence of Gender and Age of Teachers on Teaching: Students Perspective. Int.J.Curr.Microbiol.App.Sci. 7(01): 2436-2441. doi: https://doi.org/10.20546/ijcmas.2018.701.293 